\title{
MACROECONOMIC INDICATORS OF HAPPINESS: CASE OF THE EUROPEAN UNION COUNTRIES
}

In Happiness And Contemporary Society : Conference Proceedings Volume (Lviv, March, 20-21, 2021). Lviv: SPOLOM, 2021. P. 105-109. https://doi.org/10.31108/7.2021.23

ISBN 978-966-919-697-2 
https://doi.org/10.31108/7.2021.23

FERUNI Nerajda

Master of Science, Assistant Lecturer, Mediterranean University of Albania (Tirana, Albania)

\section{MACROECONOMIC INDICATORS OF HAPPINESS: CASE OF THE EUROPEAN UNION COUNTRIES}

The aim of this paper is to test empirically the relationship between life satisfaction, another term used for happiness, and macroeconomic indicators such as GDP per capita, which is a proxy for economic growth, unemployment, inflation, income distribution and government expenditure in the European Union countries during the period of 2005-2017. The chosen variables are some of the most significant determinants of economic growth as well. Using the Fixed Effects model, which falls under the Panel Generalized Least Square method, the empirical results are in accordance with the literature review and suggest that unemployment and inflation have negative significant impacts on life satisfaction. Additionally, higher government expenditures and a higher level of economic growth lead to a higher level of life satisfaction in the EU countries, while unfair income distribution leads to a lower level of life satisfaction.

Keywords: life satisfaction, macroeconomic indicators, economic growth, EU

\section{Introduction}

The topic of happiness and well-being has been addressed in recent decades from different point of views, in order to identify the factors with significant impact on this phenomenon. Scholars have put great emphasis on the relationship between happiness and economic growth and many authors have conducted similar studies for the EU countries as well; however, this study focuses only on the macroeconomic indicators of happiness in these countries. Hence, this paper aims to test whether the economic growth itself and some of its significant macroeconomic indicators affect the happiness of the EU countries. In other terms, the main objective of this study is to check if the macroeconomic determinants of economic growth are the macroeconomic determinants of happiness as well. The chosen macroeconomic determinants are GDP per capita, government expenditure, unemployment, inflation and income distribution, while life satisfaction scores present the happiness levels in the EU countries for the period 2005-2017.

The hypotheses of this study are:

H1: GDP per capita and Government Expenditures have positive significant impacts on the life satisfaction of the EU countries.

$\mathrm{H} 2$ : Unemployment and Inflation have negative significant impacts on the life satisfaction of the EU countries.

H3: Unfair income distribution has a negative significant impact on the life satisfaction of the EU countries.

\section{Literature Review}

Terms such as subjective well-being or life satisfaction may refer to the same phenomenon, that of happiness (Easterlin, 2010). Thus, different terms and measurements are used in different studies to explain the patterns of happiness. Researchers have widely studied the impact of economic growth on happiness levels. In their study, Hagherty and Veenhoven (2003) argue that increasing national income 
results in a higher level of national happiness, however, the short-term effect is larger than the long-term effect. Easterlin and Angelescu (2009) find no significant impact of the long-term rate of growth of GDP per capita on the happiness levels in none of the chosen group of countries, being they developed, developing or transition economies. To the contrary, higher levels of income per capita are associated with increased life satisfaction, still the coefficient of the impact is small and it seems that in developed nations, economic growth progress buys only a small amount of extra happiness (Blanchflower, 2007; Oswald, 1997; Tella, MacCulloch and Oswald, 2003). Regarding the EU countries, Hysa and Mansi (2020) suggest that there is a positive association between the GDP per capita and happiness levels in these countries.

When it comes to the impact that unemployment and inflation have on the level of happiness, authors widely agree that there is a negative relationship between unemployment and life satisfaction, as well as between inflation and life satisfaction. In their study, Tella et al (2003) find evidence that social well-being is a decreasing function of inflation and unemployment and the estimated effects of the unemployment rate and inflation are significant. Likewise, Blanchflower (2007) and Mohammad (2016) suggest that unemployment and inflation have depressing effects on happiness, but the negative impact of unemployment rate on happiness is higher than the impact of inflation. Abounoori and Asgarizadeh (2013), Kacapyr (2008), Sanfey and Teksoz (2007) find supporting evidence on the inverse relationship between unemployment and life satisfaction and they agree there is a negative relationship between inflation and life satisfaction as well. All the above-mentioned authors agree on the positive association between GDP per capita and happiness.

In their paper, Abounoori and Asgarizadeh (2013) introduce another important macroeconomic indicator: government expenditure. Their empirical analysis suggests a positive significant correlation between government expenditures and happiness levels. In the study of Kacapyr (2008), the ratio of government expenditure to GDP proved to be statistically insignificant, however, the simple correlation coefficient indicates a positive association between the share of government in the economy and life satisfaction. Ram (2009) supports the previous findings of a positive association between government consumption and happiness, while Perović and Golem (2010) argue that government expenditure influences happiness positively up to a certain threshold, and negatively afterwards.

Another important indicator being reviewed in this section is the income distribution and its impact on life satisfaction. The empirical results of Sanfey and Teksoz (2007) show that the higher the income inequality measured by the Gini coefficient is, the lower is the life satisfaction of people. However, Schröder (2018) argue that life satisfaction is unaffected by long-run levels of inequality, but by changes of inequality over time. Yet, Delhey and Dragolov (2014) argue that countries with more income inequality tend to have less social trust that leads to lower life satisfaction. Among wealthy countries, people distrust each other when inequality is higher. Hence, life satisfaction lowers. Similarly, Verne (2011) finds that income inequality has a negative and significant effect on life satisfaction, but García-Muñoz, Milgram-Baleix and Odeh-Odeh (2019) emphasize that income inequalities reduce the well-being of individuals if opportunities are low, but inequality is not relevant for life satisfaction if opportunities in the country are high.

Data and Methodology

To test empirically the impact of macroeconomic indicators on life satisfaction, multiple regression analysis is used as an analytical tool to identify the regression 
equation and to derive quantitative conclusions on the effects that the chosen independent variables have on the dependent variable. The independent variables are GDP per capita (GDP), government expenditure (GE), inflation (INF), unemployment (UNM) and income distribution (GINI), while the dependent variable is life satisfaction (LS). Hence, the sample of this paper consists of secondary data collected from reliable sources. The macroeconomic indicators are taken from the World Bank, while the life satisfaction scores are from Our World in Data Website. There are 282 observations in total, annually compounded, for $27 \mathrm{EU}$ coutries for the period 2005-2017. The period is adjusted based on the availability of data, still, this study deals with unbalanced panel data. The multiple regression equation can be presented as follows:

$$
\mathrm{LS}=\alpha_{0}+\alpha_{1} \log \left(\mathrm{GDP}_{\mathrm{ij}}\right)+\alpha_{2} \log \left(\mathrm{GE}_{\mathrm{ij}}\right)-\alpha_{3}\left(\mathrm{INF}_{\mathrm{ij}}\right)-\alpha_{4}\left(\mathrm{UNM}_{\mathrm{ij}}\right)-\alpha_{5}\left(\mathrm{GINI}_{\mathrm{ij}}\right)+\mathrm{eij}
$$

Life satisfaction measures how people evaluate their life as a whole rather than their current feelings. It is reported on a scale from 0 to 10 , with 10 representing the highest possible level of satisfaction. GDP per capita, a proxy for economic growth, is gross domestic product divided by midyear population and it is measured in constant 2010 \$US. Government Expenditure includes all government current expenditures for purchases of goods and services and it is measured in constant 2010 \$US. Unemployment refers to the share of the labor force that is without work but available for and seeking employment and it is measured as a percentage of total labor force, while inflation as measured by the consumer price index is in percentage as well. Lastly, Gini coefficient measures the fairness of income distribution, 0 represents perfect equality, while an index of 100 implies perfect inequality.

\section{Empirical Results, Analysis and Discussion}

Prior to running the regression, all the necessary tests were conducted to avoid any biases in the results. The variables are stationary in levels, the error terms are homoscedastic, there is no multicollinearity problem and the residuals are not correlated with the independent variables. Based on the results of the Hausman Test, which assumes that a Random Effect model is more appropriate than a Fixed Effect model, in this paper, a Fixed Effect model is applied (P-value of Hausman Test $=0.0289<0.05$ ). The Fixed Effect Model falls under the Panel Generalized Least Square method.

Table 1. Correlation Matrix

\begin{tabular}{|c|c|c|c|c|c|c|}
\hline & LS & UNM & LGE & LGDP & INF & GINI \\
\hline LS & 1.000000 & -0.406376 & 0.473378 & 0.851791 & -0.192221 & -0.548463 \\
\hline
\end{tabular}

Source: Compiled by the Author

As Table 1 shows, it seems there is a strong positive correlation between economic growth and life satisfaction in the EU countries, while there is a moderate negative correlation between unfair income distribution and life satisfaction. The correlation matrix shows moderate levels of positive correlation between government expenditure and life satisfaction, while it seems there is a moderate negative correlation between unemployment levels and life satisfaction in the EU countries. Regarding the relationship between inflation and life satisfaction, the correlation matrix shows a weak negative correlation between these two variables. However, the regression equation is going to present results that are more accurate.

The regression equation that emphasizes the above-mentioned relationships is as follows: 
$\mathrm{LS}=-2.811+0.903 \log \left(\mathrm{GDP}_{\mathrm{ij}}\right)+0.072 \log \left(\mathrm{GE}_{\mathrm{ij}}\right)-0.038 \mathrm{UNM}_{\mathrm{ij}}-0.046$ $\mathrm{INF}_{\mathrm{ij}}-0.046 \mathrm{GINI}_{\mathrm{ij}}+\mathrm{e}_{\mathrm{ij}}$

All the independent variables are significant at 5\% level of significance. Given the economic growth, presented by the GDP per capita, a 1\% increase in GDP per capita, ceteris paribus, tends to increase life satisfaction in the EU countries by 0.009 points. Similarly, a $1 \%$ increase in government expenditure, ceteris paribus, tends to increase life satisfaction by 0.00072 points. Thus, the first hypothesis of this paper can be accepted. Even though the impact appears to be very small in both cases, still, it is highly significant and in accordance with the literature review. Additionally, $1 \%$ increase in unemployment levels, ceteris paribus, tends to decrease life satisfaction in the EU countries by nearly 0.04 points. Likewise, $1 \%$ increase in inflation levels, ceteris paribus, tends to decrease life satisfaction by nearly 0.05 points. Hence, the second hypothesis is accepted. Lastly, when it comes to Gini coefficient, a 1-point increase in Gini coefficient, ceteris paribus, tends to decrease life satisfaction by nearly 0.05 points, meaning that unfair income distribution (income inequality) makes people less happy in the EU countries. The third hypothesis is accepted as well. In all cases, the results are in accordance with the literature review. In the EU countries, economic growth and government expenditure increase life satisfaction, while unemployment, inflation and income inequality have depressing effects on life satisfaction.

\section{Conclusion}

The topic of happiness and well-being is of highly importance and in the recent decades, different studies have been conducted to identify factors with significant impact on this phenomenon. This study shows that economic growth and government expenditures have positive impacts on life satisfaction in the EU countries, while unemployment, inflation and income inequality affect life satisfaction negatively. It seems that richer countries with higher government expenditure, less unemployment, less inflation and higher income equality are happier. In the EU countries, the negative impact of unemployment, inflation and income inequality on life satisfaction is higher compared to the positive impact of economic growth and government expenditure; hence, the respective governments should take the necessary measurement to tackle this issue.

\section{REFERENCES}

1. Abounoori, E., \& Asgarizadeh, D. (2013). Macroeconomic Factors Affecting Happiness. International Journal of Business and Development Studies, 5(1), 5-22.

2. Blanchflower, D. G. (2007). Is Unemployment More Costly Than Inflation? NBER Working Paper No.13505.

3. Delhey, J., \& Dragolov, G. (2014). Why Inequality Makes Europeans Less Happy: The Role of Distrust, Status Anxiety and Perceived Conflict. European Sociological Review, 30(2), 151-165. 
4. Easterlin, R. A. (2010). Happiness, Growth and the Life Cycle. Europe's Journal of Psychology, 7(2), 395-398.

5. Easterlin, R. A., \& Angelescu, L. M. (2009). Happiness and Growth the World Over: Time Series Evidence on the Happiness-Income Paradox. IZA Discussion Papers 4060, Institute of Labor Economics (IZA).

6. García-Muñoz, T. M., Milgram-Baleix, J., \& Odeh-Odeh, O. (2019). Inequality and Life Satisfaction in Low-and Middle-Income Countries: The Role of Opportunity. Societies, 9(2), 37.

7. Hagherty, M. R., \& Veenhoven, R. (2003). Wealth and Happiness Revisited Growing National Income Does Go with Greater Happiness. Social Indicators Research, 64, 1-27.

8. Hysa, E., \& Mansi, E. (2020). Happiness and Economic Growth: Western Balkans and European Union. In Happiness And Contemporary Society: Conference Proceedings Volume , (pp. 105-113).

9. Kacapyr, E. (2008). Cross-Country Determinants of Life Satisfaction with Life. International Journal of Social Economics, 35(6), 400-416.

10. Mohammad, J. (2016). Assesing the Factors Affecting on Happiness in Islamic Countries. Journal of Macroeconomics, 11(22), 65-84.

11. Ortiz-Ospina, E. (2013). Happiness and Life Satisfaction. Published online at OurWorldInData.org. Retrieved from https://ourworldindata.org/happinessand-life-satisfaction

12. Oswald, A. J. (1997). Happiness and Economic Performance. The Economic Journal, 107(445), 1815-1831.

13. Perović, L. M., \& Golem, S. (2010). Investigating Macroeconomic Determinants of Happiness in Transition Countries: How Important is Government Expenditure? Eastern European Economics, 48(4), 59-75.

14. Ram, R. (2009). Government Spending and Happiness of the Population: Additional Evidence From Large Cross-Country Samples. Public Choice, 138, 483-490.

15. Sanfey, P., \& Teksoz, U. (2007). Does Transition Make You Happy? Economics of Transition, 15(4), 707-731.

16. Schröder, M. (2018). Income Inequality and Life Satisfaction: Unrelated Between Countries, Associated Within Countries Over Time. Journal of Happiness Studies, 19(4), 1021-1043.

17. Tella, R. D., MacCulloch, R. J., \& Oswald, A. J. (2003). The Macroeconomics of Happiness. Review of Economics and Statistics, 85(4), 809-827.

18. Verne, P. (2011). Life Satisfaction and Income Inequality. Review of Income and Wealth, 57(1), 111-127.

19. World Bank, World Development Indicators (2019). Retrieved from https://data.worldbank.org/indicator 